頸 椎 分 離 症 $の 2$ 例

宮崎市・原田外科病院 整形外科

高㭇先歩

\title{
Spondylolysis of the Cervical Spine; Report of Two Cases
}

By

\author{
S. Takatsuki \\ Division of Orthopedic Surgery Harada \\ Surgical Hospital, Miyazaki
}

It is rare to find spondylolysis or spondlylolithesis in the cervical region. In the literature only 18 cases of spondylolysis have been reported. Another 2 cases are here presented.

Case 1.N. U. a male, 19 years old had slight pain in the neck after a car accident. Physical examination revealed only slight disturbance of motion of the neck. Roentgenograms showed spondylolysis and spina bifida of the 4th cervical vertebra with hypoplastic articular pillars. The 4th cervical vertebra slightly displaced forward on the 5 th cervical vertebra. Superior articular processes of the 5th cervical vertebra also doformed. Conservative treatment was done with success.

Case 2. K. W. a male, 28 years old, consulted our clinic for the headache and slight pain in the neck after a struck on his head.

Roentgenograms showed unilatleral spondylolysis of the 4th cervical vertebra with slight spondylolisthesis, and congenital fusion of the 4th and 5th cervical arch and spinous processes.

Successful treatment was the halter traction for about one month.

Follow up of the above 2 cases is 8 months and 17 months, respectively, and no symptoms are recognized during these periods.

緒言

最近, 交通事故や労働災害の増加ににもに, 䩄椎部 に愁訴を有する患者か次第に增加し，頸椎のX線検査 をする機会が多くなつてきている，その際，時折頸椎 の先天性異常が発見され，外鹪に上る変化之間違われ やすい.

私は最近，2 例の頸椎分離症を経験したが，宵椎分 離症はほとんど腰椎にみられ，頸椎での発生はきわぬ てめずらしいので，いささかの交献的考察を加えて報 告する。

症
症例 1. 例
主訴 頸部運動痛

家族歴，既往歴特記すべきてとはない，

現病歴 昭和 43 年 8 月 5 日夜, 軽自動車を運転し, 時速 $20 \mathrm{~km}$ 位で普通車に追突しれ．その際頸部の前 屈を強制され頚頂部を車の天井に打つれとのととであ る: 頭痛はなかつれが，形部に運動痛が生じれので受 傷の翌日来院した。

現症全身的には著変は認められない，頸椎棘突起に は吒打痛も圧痛もないが，左項筋の中央部には軽度の 圧痛がある，前屈位，中間位，後屈位での軸在痛はな い. 腕神経叢の圧痛もなく, Allen 症状, Adson 症 状, Halstead 症状屯認めない，腱反射は正常で知覚 障害もない，頸椎前後屈運動，左側屈は正常である が, 右軸旋 $45^{\circ}$ 以上, 左軸旋 $50^{\circ}$ 以上, 右側屈 $25^{\circ}$ 以 上で左項部中央部に疼痛がある.

$\mathrm{X}$ 線所見前後像では第４. 頸椎棘突起潜在性脊椎披 


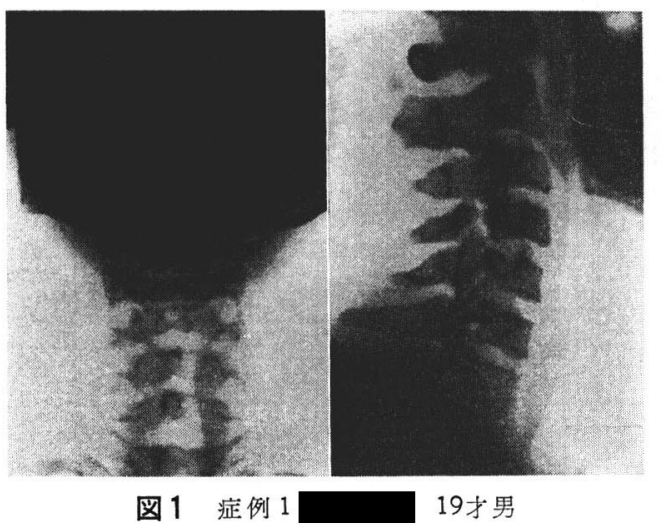

裂を認める．側面像では，第 4 頸椎関節突起間部に明 白な分離が認められ，第 4 頸椎々体は第 5 頸椎々体に 対しわずかに前方に之つている. 第 $4 / 5$ 頸椎々間腔の 狭小はない，第 4 頸椎上下関節突起は形成不全的で, 第 5 頸椎上関節突起は変形している (図 1 ). 動態撮 影ではこりの増加は認められない.なお腰椎にはレ線 上異常を認めない.

治療および経過：莖椎綿包帯固定，鎮痛剂，ビタミ ン $\mathrm{B}_{1}$ 剂の内服を行なつれところ, 疼痛は 4 日目より なくなり，2 週後固定を除去しれ. 8 力月後の現在, 無症状で平常勤務に復している.

症例 2 28 才, 男子, 建設省官吏.

主訴 頭痛, 項部痛.

家族歷，既往歴 特記すべきことはない.

現病歷 昭和 42 年 11 月 30 日仕事中シャベル車のバ ケット（重さ 2 トン）が下降してきて，下で働いてい る,ヘルメットをかがつた頭にぶつつかりはねとばさ れた，それ以後時々頭痛がある. 頭痛および軽度の項 部痛を訴元, 受傷後 5 日目に来院した。

現症後頭部自発痛を軽度訴えるが, 瞳孔対光反射, 輻軖反射之も正常である. 第 $4 \cdot 5$ 頸椎棘乫起部に吒 打痛, 圧痛があり, 両側項筋中央部に圧痛がある. Allen 症状, Adson 症状, Halstead 症状はなく, 腕 神経丵の圧痛むない，上椎腱反射は正常である．膝蓋 腱反射, アキレス腱反射は両側ともやや穴進している が病的反射はない. 頸椎運動は後屈が疼痛のためやや 制限されているが，その他は正常である.

$\mathrm{X}$ 線所見前後像では, 第 5 頸椎棘突起陰影が大きく 塊状に認められるが，第 4 頸椎棘突起ははつきりしな い. 側面像では第 4 - 5 頸椎棘突起, 後部椎弓の瘜合 があり，第 4 頸椎関節哭起間に明らかな分離が認めら

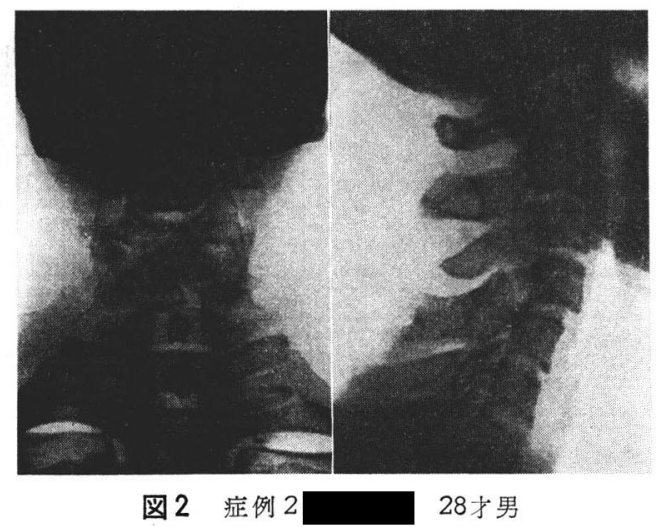

れ，第 4 頸椎々体はやや前方に之つている(図 2 ). 斜位像では右斜位で第 4 頸椎椎弓根部に三角形の骨陰 影（横突起）があり，その頂部で，第 $4 \cdot 5$ 椎間孔が 明らかに連結している. 左斜位では形成不全の椎弓根 か認められる. 動態撮影では前屈により軽度の分離部 の離解があるが椎体の之りの増加は殆んどない。なお 腰椎にはレ線上異常を認めない。

治療扎よび経過直ちに入院, 重垂 $3 \mathrm{~kg}$ でグリッソ ン毫引を開始し, 同時に鎮痛消炎剂, ビタミン剂, 筋 驰䌊剂などを投与した。10日目より疼痛は全くなくな り, 4 週間の入院後, 頸椎固定用装具を装着し退院し た. その後外来にて経過を観察するに, 一時第 5 頸椎 棘突起に压痛を訴えたのみであり，3 月月で装具を完 全除去した. 1 年 5 力月後の現在, 患者は全く無症状 で職場に復帰している.

\section{考按}

頸椎の先天性異常としては，2 個またはそれ以上の 椎体の湶合, 椎弓, 棘突起の痖合, 半椎体, 春椎披 裂, 侧彎などが比較的しばしば見られる. 一方奉椎分 離症ないし之り症の頻度は, 一般に 4 5\%とみなさ れ，その報告はほとんぞ腰椎部であり, 靧椎部の発生 はきわめて稀である。

文献上, 頸椎々弓根部の分離は, 同部の Aplasie 之 して報告されている偏側分離の例之，偏側または両側 の椎弓根部の分離を伴つた方り症として報告されてい る例とがあるが，その両者とも稀で，私が交献上集め 得た例は表 1 の如くである. その内 Hadley の症例 2 と 3 は後の論文で本症でない之否定されているので合 計18例である. 今回これらに自験例 2 例を加えて考察 を試みる。 
表 1

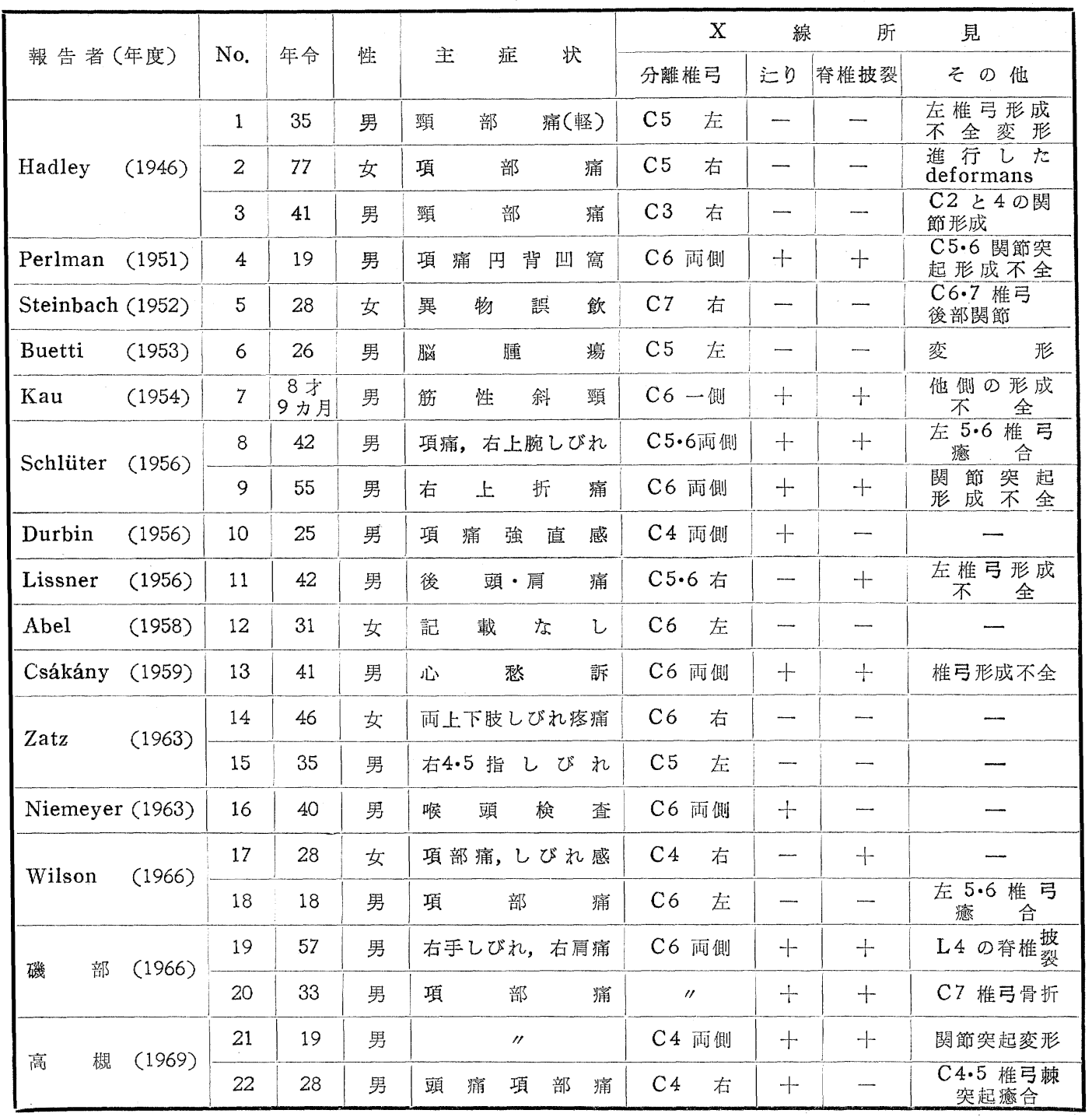

年令・性: 本症発見時年令 は 8 才 9 力月より 57 才 までであり，20才代と 40 才代代発見されたあのが多 い. 乙れは本症の発見動機を考慮するとき興味あるこ とである. 男 16 例, 女 4 例で男に圧倒的に多い。

発生部位: 第 4 莖椎 4 例, 第 5 頸椎 5 例, 第 6 頸椎 12 例, 第 7 莖椎 1 例 ( 2 椎体分離例 2 例) で, 第 6 頸 椎江多心。耐側性 10 例, 偏側性 12 例（右 6 例, 左 5 例, 不明 1 侧)で, 偏側性の場合の左右差はない。 Csákány (1959) は顓椎の椎弓分離, 軽度の之り, 潜 在性脊椎披裂の合併は, 第 6 形椎にのみ認められる之
し， $\mathrm{C}_{6}$-Symptomenkomplex と呼んだ．第 4 頸椎例 は Durbin (1956) の1例 および Wilson (1966)の 1 例であり，自験例は 2 例之も第 4 形椎であつた。

症状 : 形部, 後頭部, 肩, 上肢などの疼痛, 靧椎運 動制限, 項筋緊張, 筋力低下, 上肢しびれ感, 触覚低 下等が記載されているが，偶然化発見されるとの報告 あある (Csákány, Niemyer). さらにまた, 本症発 見時の病歴をみると, 頸部の外傷あるいは变形性脊椎 症による症状のため来院している例が多く，本症は元 来無症状の屯の之思われる. 私の症例は 2 例之屯外傷 
を契機として発見された。

臨床所見: Perlman and Hawes (1951)は二椎体 間の凹曧を認めているが，そのほかの例にはない，棘 突起, 項筋の王痛, 頸椎運動制限とくに軸旋制限, 円 背などが認められた例もあるが，特異的な所見はな 认.

X線所胃 : 多くは第 6 頸椎, ときに第 5 頸椎, 第 4 頸椎または第 7 頸椎の椎马関節突起間部の久損, 同椎 体の前方へのわずかなうり, 潜在性雪椎披裂が認めら れる.しかし Schülter の例では潜在性脊椎披裂はな く, また私の第 2 例目では第 4 ・5 頸椎棘突起, 椎马 の癒合があり奉椎披裂はない，偏側分離の場合，他側 の椎弓形成不全が認められる. その他, 上下関節突起 の形成不全あるいは変形がみられる. Hadley は $45^{\circ}$ 斜位像で分離が明瞭となり，同部の椎間孔の拡大がみ とめられるとのべた. 動態撮影における椎体間の運動 䇢囲の程度については, Niemyer, 磯部らが報告して いるが，私の症例に执いては表 2 の如くであり， $3 / 4$ 間あるいは 4/5 間に不安定性があるとは思われなかつ た. 脊䯣腔造影術では, 搪大した椎間孔から出る $2 つ$ の神経根の共通根㰸像をみるといわれているが, Wilsonは鑑別彰率上てれを要する事は殆んどないと のべ, 私の 2 症例であ脊䯣腔造影術は必要としなかつ た.

鑑別診断としては, 外賃による骨折があるが, 重度 の外傷歴の欠除, 分離部の形態, 他の先天的異常の合 併などより鑑別される. 更にまた, 椎体骨折のない関 節突起間部骨折自体もきわめて稀である. その他, 偏 側性の場合, 一㑡椎間孔の挔大をみる疾患であるいわ ゆる dumbbell-tumor および椎骨動脈のねじれによ る二次的骨変化 (Hadley (1958)) があるが, レ線像 の詳細な検討を行なうことにより鑑別可能である. 成因論 : 重度の外傷の欠除, 偶然溌見された症例の 多いこと, 他の先天性異常の合併などから, 外傷説は 否定される. 腰椎分離症, 达り症の成因としては, 生 下時には存在せず, 小児が起立, 歩行を開始し, 腰椎 前彎を形成するようになつた時期に, 先天的な構造上 の弱点部位である関節突起間部に分離を生じ, 漸次元 り症へ移行する, という説が主流を占めている. 頸椎 そおいても同様生下時には認められないとと, 偏側性 の場合, 他側の形成不全をみることより, 先天性形成 不全の上に, 負荷によつて発生した Umbauzone であ るとする考えが多いようである.しかし頸椎では，本
症の原因としての静力学的および動力学的負荷の意義 は, 腰椎の場合ほど本質的ではなく ${ }^{12)}$, 椎弓の先天性 形成不全ないし欠損により大きな意義が与えられるだ ろう. 家族的発性の報告はない. 自験例では家族が遠 隔地に居るため調查出来なかつた.

治療 : 従来, 治療法についてのへててる文献は少な いが, Durbin は寛和な徒手矯正後, 卧床させるとと により 4 日後無症状となつた例に, 患者の職業を考虑 に入れて, 後方固定術を行なつている. また Kauは, 合併する筋性斜頸に開放切腱術を施行し, 頸椎に対す

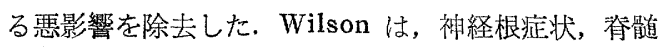
症状を伴う 1 例に，第 4 頸椎の変形した右横突起の内 側の切断を行なつている，私の症例 1 では，2週間の 綿包帯固定が行なわれたのみで無症状となり，症例 2 ではグリッソン牽引で 10 日目に無症状となり，その 後用心のため頸椎固定装具を用いた. 結局, 頸椎分離 症ないし汇り症では, 重大な症状をおてしたという報 告例はほとんどない.したがつて，その治療ししては 本症発見の誘因となつた頸椎捻挫あるいは変形性脊椎 症の治療が行なわれるだけで十分であり，本症自体に 対す万頸椎固定術の適応はほとんどないものと思われ る.

\section{結語}

以上，私は稀なる頸椎分離症の 2 例を報告し，あわ せて文献的考察を加えた。

（御指導御校閲をたまわつた恩師伊丹康人教授に樑 謝し，また本症の発表の機会を与えて下さつた原田外 科病院院長原田正博士に感謝する。)

\section{参考文 献}

1) Abel, M. S. : Moderately severe whiplash injuries of cervical spine and their roentgenologic diagnosis. Clin. Orthop. 12:189 208, 1958.

2) Buetti, C. : Zur Röntgendiagnostik seltener Fehlbildungen der Halswirbelsäule Radiolo. gia Clinica. $22: 141 \sim 161,1953$.

3) Csákány, G. und Álmos, S. : Echte Spondylolisthese der Halswirbelsäule $\left(\mathrm{C}_{6}\right.$-Symptomenkomplex) Fortschr. Geb. Röntgenstr. 91 : 277 280, 1959.

4) Durbin, F. C.: Spondylolisthesis of the cervical spine, J. Bone and Joint Surg. 38-B : 734 735, 1956. 
5) Hadley, L. A. : Congenital absence of pedicle from the cervical vertebra, Amer. J. Röntgenol. $55: 193 \sim 197,1946$.

6) Hadley, L. A. : Tortuosity and deflection of vertebralartery. Am. J. Roentgenol., 80 : 306 312, 1958.

7) 磯部鱙・他：頸椎に括ける分離症の 2 症例, 整 形外科. $17: 285 \sim 289$, 1966.

8) Kau, R. : Spondylolisthesis der Halswirbelsäule Archiv für orthodädische und Unfallchirurgie. 46:502 507, 1954.

9) Lissner, J. : Spondylolisthese der Halswirbelsäul Fortschr. Geh. Röntgenstr. 84 : 626 $628,1956$.

10) Niemeyer, T. H. and Penning, L. : Functional Roentgenographic Examination in a Case of Cervical Spondylolisthesis J. Bone and Joint Surg. 45-A : 1671 1678, 1963

11) Perlman, L. C. R. and Hawes, M. L. E. : Cervical Spondylolistheis J. Bone and Joint Surg. 33-A : 1012 1013, 1951.

12) Schlüter, K. : Über Spondylolisthesis der Halswirbelsäule Med. Klin. 24 : 1018 1020, 1956.

13) Steinbach, H. L., Boldrey, E. P. and Sooy F. A. : Congenital Absence of the Pedicle and Superior Facet from a Cervical Vertebra Radiology. $59: 838 \sim 840,1952$.

14) Wilson, C. B. and Norrell, H. A. : Congenital Absence of a Pedicle in the Cervical Spine. Amer. J. Röntgen. 97 : 639 647, 1966.

15) Zatz, L. M., Burgess, P. W. and Hanbery, J. W. : Agenesis of Pedicle in cervical spine J. Neurosurg. 20: 564 569, 1963.

\title{
五島列島における脊椎分離症について（第 1 報）
}

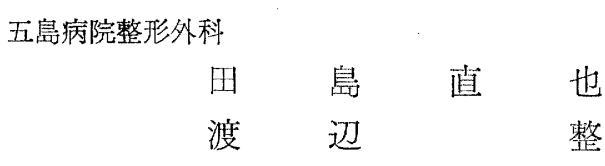

黒川整形外科

黒 川 典男

長崎大学 整形外科

林広 三 郎

\section{On Spondylolysis in the Goto Islands, The First Report}

By

\author{
N. Tajima \& T. Watanabe \\ Goto Hospital, Nagasaki \\ N. Kurokawa \& K. Hayashi \\ Deparment of Orthopedic Surgery \\ Nagasaki University, School \\ of Medicine
}

Reported here is the result or a study on all spondylolysis patients who were found at the Orthopedic Clinic, Goto Hospital. in the four year period since its opening in May 1965 till April 1968.

There were 516 lumbago patients including 294 male and 222 female patients. Among them 123 patients (23.8\%) had spondylolysis including 83 male $(28.2 \%)$ and 40 female $(18.2 \%)$ 